Consumer Policy Remedies and Consumer Segment Interactions

Author(s): Christine Moorman and Linda L. Price

Source: Journal of Public Policy \& Marketing, Vol. 8, Health and Safety Issues (1989), pp. 181203

Published by: American Marketing Association

Stable URL: http://www.jstor.org/stable/30000320

Accessed: 23/09/2013 16:18

Your use of the JSTOR archive indicates your acceptance of the Terms \& Conditions of Use, available at

http://www.jstor.org/page/info/about/policies/terms.jsp

JSTOR is a not-for-profit service that helps scholars, researchers, and students discover, use, and build upon a wide range of content in a trusted digital archive. We use information technology and tools to increase productivity and facilitate new forms of scholarship. For more information about JSTOR, please contact support@jstor.org. 


\title{
Consumer Policy Remedies and Consumer Segment Interactions
}

\author{
Christine Moorman and Linda L. Price
}

Christine Moorman is Assistant Professor of Marketing, School of Business, University of Wisconsin. Linda L. Price is Assistant Professor of Marketing, College of Business, University of Colorado. Authors are listed in alphabetical order to reflect equal contributions. The authors would like to thank four anonymous reviewers for their comments.

JPP\&M, Vol. 8

(1989), 181-203
This paper introduces a framework for examining consumer and market problems as a function of consumer segment interaction patterns. Three patterns of interactions are described as consisting of positive, negative, or no spillovers among consumer segments. The efficacy of regulatory remedies is shown to be affected by the type and extent of these interaction patterns. The paper complements and extends conventional aggregate cost-benefit approaches in three ways: 1) by treating consumer interactions as a central feature of the market system; 2) by focusing on how various interaction patterns affect the distribution and intensity of spillovers among consumers; and 3) by describing how policy remedies can be used to facilitate or overcome these interaction patterns.

A large volume of economic analysis evaluates regulation against the standard of economic efficiency. Proponents of economic efficiency argue that regulation should be undertaken only when the market fails [Mazis, Staelin, Beales and Salop 1981; Stokey and Zeckhauser 1978]. ${ }^{1}$ From this perspective, the goal of intervention is restored efficiency. Current policy focuses on aggregate efficiencies across strata of society arguing that regulation should be undertaken only if net benefits to buyers and sellers exceed net costs [Craswell 1985; Ford and Calfee 1986].

The present paper introduces a framework for examining consumer policy remedy choice as a function of consumer interaction patterns. This framework complements and extends conventional cost-benefit analysis in three ways. First, although the efficiency of regulatory remedies is important, their distribution of remedy costs and benefits or equity is also important [Crandell 1988; McCraw 1984; Meier 1985]. That is, if net benefits exceed net costs and certain consumers always reap the costs, the regulation is unfair, and fairness matters [Beauchamp and Bowie 1983; Kelman 1981; Rawls 1971]. Over the history of regulatory decision-making, policymakers have been concerned with both the equity and efficiency of their decisions and in cases of conflict, equity was viewed as more important [McCraw 1984]. Present decision-making approaches, including costbenefit analysis, do not incorporate distributional considerations thereby limiting policymakers' acceptance of this approach [Crandell 1988]. ${ }^{2}$

Second, cost-benefit analysis and its theoretical basis in economic theory, treats consumer interactions as operating outside the ideal theoretical model-a "deviation." ${ }^{3}$ We treat these interactions as a central feature of both the best and worst of our economic system and argue that important equity and fairness issues are often the consequence of these interactions. For example, when the actions of one consumer negatively impacts another consumer, issues of consumer "entitlement" or rights arise [Calabresi and Melamed 1972; Donaldson 1982; Donaldson and Werhane 1982].4

Third, the ideal theoretical economic model assumes perfect information, and recognizes information asymmetry as a major obstacle to efficient operation of the market. This approach focuses on correcting information asymmetry primarily through the provision of information [Calfee and Ford 1988; Ippolito 1988]. This paper agrees that imbalances in the amount of information possessed by buyers and sellers can be offset in a variety of ways, but also acknowledges that these

Consumer Policy Remedies

181 
information asymmetries are unlikely to be eliminated. Hence, our framework focuses on the distribution and intensity of information asymmetries across consumer segments. These interaction patterns illustrate the need for both less and more restrictive regulatory remedies. Consequently, a full spectrum of policy choices from information remedies (e.g., providing product information) to market restraint remedies (e.g., banning a potentially hazardous product) are examined. The next section describes in more detail the remedy options available to policymakers.

This paper is primarily concerned with interactions among consumers rather than interactions among buyers and sellers or among sellers. Obviously the interests of both sellers and buyers are important to policymakers [Mazis et al. 1981]. However, considering the distributional effects of regulatory decisions on consumers makes the topic both more tractable and identifies issues that might go unnoticed in total market analysis.

The Spectrum of Consumer Policy Remedy Choices

Information Remedies
Past research has tended to focus on consumer and market considerations affecting the design and implementation of information remedies or market restraint remedies [Capon and Lutz 1979; 1983; Federal Trade Commission 1979; Mazis et al. 1981], and not on factors affecting choices between these classes of remedies. This section reviews the literature on remedies available to policymakers and current perspectives on their use. In the context of this paper, we restrict our attention to information, education, and market restraint remedies. ${ }^{5}$

In general, there has been a movement away from market restraint remedies and toward information remedies [Bettman, Payne and Staelin 1986; Breyer 1982; Federal Trade Commission 1979; Gage 1979; Hadden 1986]. Consequently, most recent research concerns how information remedies can be used effectively to alleviate market failures [Beales et al. 1981a; Day 1976; Federal Trade Commission 1979; Hadden 1986; Mazis et al. 1981; Mazis and Staelin 1982; Pridgen and Preston 1980; Wilkie 1982; 1983; 1985; 1986; 1987]. A more comprehensive perspective on remedy choice requires an understanding of how and where information flows in the marketplace, and when these flows are unable to support the use of information remedies for the benefit of all consumers. A discussion of education remedies is also included because they may frequently be appropriate for remedying seller-buyer information asymmetries and negative consumption spillovers. The remainder of this section reviews a more detailed continuum of regulatory remedies by documenting differences among information, market restraint, and education remedies and presenting finer distinctions within each remedy type.

The Federal Trade Commission [1979] has proposed a restrictiveness continuum separating information remedies into two categories: those seeking to increase the number of speakers providing information (speaker remedies), and those affecting the content of the information provided by sellers (message remedies) [pp. 184-89].

Speaker remedies attempt to increase the flow of information to consumers by relying on market forces with minimal government interference [Pridgen and Preston 1980]. These remedies include increasing the number of advertisers by removing state laws, voluntary codes of trade associations, and professional codes of ethics that impede the flow of information. As a result of this increased information, these remedies reduce consumers' search costs and facilitate comparative shopping. ${ }^{6}$ However, in some situations the lifting of formal restrictions to produce information fails to increase the amount of information available. For example, in many local markets, social factors exert pressure to maintain prices and restrict the flow of information such as in the provision of real estate, medical, and funeral services [Pridgen and Preston 1980]. 
Market Restraint Remedies

Education Remedies

The Effect of Consumer Interaction Patterns on Policy Remedy Choice
Message remedies, on the other hand, directly constrain the type of information sellers can provide and are therefore viewed as more restrictive than speaker remedies. One class of message remedies, affirmative disclosures, requires firms to inform potential customers of negative product or service facts they might otherwise fail to disseminate [Wilkie 1986]. Therefore, message remedies may also increase the amount of information in the marketplace. However, because the seller can often avoid the disclosure requirement by changing the product claim, message remedies may not increase information [Pridgen and Preston 1980].

Market restraint remedies constrain the level of quality firms offer to the market [Stern and Eovaldi 1984]. Thus, market restraint remedies can involve banning or restricting the manufacture, sale, and/or use of products and services in the marketplace. These remedies are appropriate when weaknesses in market forces can not be sufficiently mitigated, at a reasonable expense, by promoting information flows. Market restraint may also be necessary if the probability or consequences of risk posed by product use are too high and choice is deemed inappropriate (e.g., the use of flammable children's pajamas) or when the possibility of spillovers requires collective decision-making and action (e.g., dumping pollutants) [Hadden 1986].

Education remedies attempt to provide concepts and explanations that enable consumers to choose more effectively [Thorelli and Thorelli 1977, pp. 24-25]. Like information remedies, education remedies seek to restore the equality between buyers and sellers. However, the basic underlying philosophies of these remedies differ. Education remedies are most useful when consumers are without the requisite knowledge and skills to use information and the mere increase of information does nothing to foster these capabilities (cf., Moorman [1988] for a discussion of the failure of nutrition information programs). However, sometimes the disparity between buyers and sellers can not be eliminated because educating consumers is too expensive or time-consuming. In such cases, market restraint remedies may be necessitated.

Policy decisions rest on assumptions about the nature and type of interactions among consumer segments [Capon and Lutz 1979; 1983; Day 1976; Feick, Herrmann and Warland 1986; Ford and Calfee 1986; McCollough and Best 1980]. This paper introduces a framework for explicitly analyzing the relationship between consumer interaction patterns and policy remedy choice. Virtually no research or theory has directly addressed this relationship.

The appropriateness of policy remedies across three types of consumer segment interaction (or spillover) patterns is examined. The three types of consumer segment interaction patterns considered are as follows: 1) positive interactionsthe actions of one segment of consumers and/or government or firm activities spill over to affect other segments in positive ways; 2) negative interactions-the actions of one segment of consumers and/or government or firm actions directed to one segment of consumers spill over to harm or restrict the choices of other consumers; 3 ) incomplete interactions - the actions of one segment of consumers and/or government or firm actions do not spill over to either positively or negatively affect other consumers. ${ }^{7}$

Interactions among consumers may be relatively direct as when one consumer offers a recommendation to another about where to get the lowest price on a product [Price, Feick and Higie 1987] or one consumer consumes products that adversely affect others who are not consuming (e.g., secondary smoke). On the other hand, interactions may be relatively indirect as when one group of consum- 
Positive Consumer Segment Interaction Patterns

Policy Considerations ers' purchase decisions affect the variety, quality, and prices of products offered by firms [Thorelli and Thorelli 1977; Mazis et al. 1981].

In choosing consumer policy remedies to overcome or facilitate these interaction patterns, this framework adheres to the current policy orientation of favoring less government interferences and less restrictive remedies. Consequently, within each of three types of interaction patterns (positive, negative, and incomplete), policy remedies are examined in terms of their ability to correct consumer and market problems by enhancing the flow of information (speaker and message remedies), improving consumers' knowledge/skill base (education programs), or lastly, by restricting market offerings (market restraint remedies). Table 1 summarizes this framework by identifying for each of the three major types of interaction patterns: 1) the target segment for different policy remedies; 2) the primary questions in policy remedy selection and;3) the objectives and strategies of different policy remedies.

Positive interactions exist when the actions of one segment of consumers and/or government or firm actions directed toward one segment spill over to affect other segments in positive ways. Most research has focused on how the abilities and activities of an informed minority of consumers or information sensitive consumers transform the market in ways that benefit all consumers [Thorelli and Thorelli 1977; Thorelli and Engledow 1980].

An informed minority can affect the market in three ways: 1) their better choices lead firms to alter their offerings; 2) their complaints pressure firms to recall or rebuild substandard products, provide relevant information, and issue guarantees and warranties; and 3) their political activism leads to government and firm actions. For example, in response to consumer outrage over sodium and sugar in baby foods, major manufacturers removed these ingredients from their product lines.

In all three cases, only a significant minority of consumers need to gather and process market information for use in their purchase decisions, complaints, or campaigns to cause government or firms to respond [Capon and Lutz 1983; Dunn and Ray 1980; Federal Trade Commission 1979; Mazis et al. 1981]. The result is improved information and products for all consumers. ${ }^{8}$ Schwartz and Wilde [1985] demonstrate this effect and suggest that the larger the ratio of informed consumers to total consumers the more likely their actions will make the market competitive. $^{9}$

When positive interactions exist, policy remedies should focus on information remedies and target information sensitive consumers [Thorelli and Thorelli 1977; Thorelli and Engledow 1980]. Several researchers have suggested information sensitive consumer characteristics that would be useful in targeting them. For example, readership of Consumer Reports, attention to direct mail, and attention to print advertising have all been associated with this segment [Price, Feick and Higie 1987; Thorelli and Engledow 1980].

Policy choices should also ensure that information sensitive consumers are targeted with information they can and will use (see Table 1). This might mean providing them with more comprehensible information, lowering the cost of acquiring and using the information, or increasing its salience [Russo 1988]. Several government and market information programs such as nutrition information [Jacoby, Chestnut and Silberman 1977; Russo et al. 1986], tire grade information [Bucklin 1974], beef grade information [Miller, Topel and Rust 1976], light lumens information [Katz and Rose 1976], annual percentage rate information [Day and Brandt 1974], energy information [Anderson and Claxton 1982; Staelin 1980] and saccharin warning information [Schucker, Stokes, Stewart and Henderson 1984] 
Table 1. Policy Remedy Choice as a Function of Consumer Interaction Patterns

Consumer Interaction Pattern

\begin{tabular}{lccc} 
& Positive & Incomplete & Negative \\
\hline Target & Information & & \\
Segment & Sensitive & Isolated & Harmed \\
\hline & Segment & Segments & Segments \\
\hline
\end{tabular}

1) Are information sensitive consumers getting the information they need to make informed choices?

Primary Questions in Policy Remedy Selection

Remedy

Objectives and Strategies
2) Facilitate market response to informed segment:

-improve communication networks between informed segment and sellers

-improve communication networks between informed segment and other consumers

3) Employ restraint remedies when societal costs of delay in market response are unacceptable

4) Use restraint remedies when costs of creating an informed segment are exhorbitant.
1) Are segments isolated from the effects of information sensitive consumers by characteristic and ability, environment, or preference heterogeneity?

2) If yes, is discrimination preference-based or characteristicbased and what are the societal costs?

3) Do preference differences make it impossible to complete the network of interactions?

1) Facilitate common markets to complete interaction network:

-incentives to sellers

-incentives to consumers

- provide accessible information exchange forums

2) Create an informed group within isolated vantaged group:

-implement consumer education programs

-implement specially designed information programs

3) Employ restraint remedies when it is impossible to create a significant minority of informed buyers in isolated segment
1) Do firm/government offerings to one segment of consumers have detrimental effects on the choices or welfare of other segments? [Problem 1]

2) Do the choices of consumers harm other consumers who do not choose? [Problem 2]
Responses to Problem 1

1) Isolate the target segment

from harmed segments:

-allow consumers to screen themselves

-restrict access of information and/or products to harmed segments

2) If isolating harmed segment is discriminatory or not cost effective consider:

-educating and/or informing the harmed segment

-impose restraint remedies on all consumers

Responses to Problem 2

3 ) If connectedness, costs and values favor accommodation of the harmed segment:

-employ information and education remedies

4) If connectedness, costs and values do not favor accommodation of the harmed segment:

-employ market restraint remedies

can be viewed as designed, in part, to create and maintain an informed segment in the market. ${ }^{10}$

Finally, because information sensitive consumers are motivated to police the market [Thorelli and Engledow 1980] and to diffuse market information to other consumers [Price, Feick and Higie 1987], policy should promote and facilitate these motivations. For example, public service messages encourage consumers to 
report bad business practices to the Better Business Bureau (i.e., policing activities) and messages could encourage consumers to share their information with other consumers (i.e., diffusing activities). By targeting information sensitive consumers with desired information, facilitating policing activities, and encouraging diffusing activities, policymakers can increase both the ratio of informed to total consumers and their impact in the marketplace. ${ }^{11}$

Policymakers may also rely on information remedies because they anticipate that the information will have a direct effect on sellers whose activities will benefit consumers. In this case, sellers anticipate the vigilance of information sensitive consumers and respond without evidence of altered consumer behavior [Padberg 1977]. After examining the open dating program, Padberg concluded, "the benefits which accrue to the consumer from this program may be more related to the sensitivity it stimulates on the part of the distributors rather than the sensitivity consumers exhibit directly" [p. 7]. In other cases, the seller may not transform the market by altering product offerings, but instead by altering their interactions with consumers. For example, the provision of information on mortgage rates works through real estate agents who directed homebuyers to institutions with the lowest rates [Olshavsky 1988, p. 232]. In both situations, policy remedies affect consumers via their direct effect on sellers.

Even in markets characterized by positive interactions among consumer segments, circumstances may cause policymakers to rely on more restrictive remedies, including restricted access to the product or removal of the product from the market. Two such circumstances, discussed below, are when technological change makes information solutions impractical and where the time lag for the natural operation of market mechanisms is unacceptable.

Information solutions may be impractical when the rate of technological change is high and it is difficult to maintain an adequate amount of knowledge to make informed choices. Preston and Bloom [1986] summarize this perspective by stating, "Paradoxically, the goals of adequate information and wise choice are made more difficult, not easier, by the contemporary explosion of new technologies and products" [p. 45]. Therefore, the decision to use information remedies should be made with awareness of the rate of technological change in the environment.

Second, informational solutions may be impractical if there is a substantial lag between informed consumers' choices or protests and sellers' reactions. For example, informed consumers can do little in the case of the fly by night operation because by the time their protests are registered, substantial harm has been incurred by many consumers and the culprits have left town. Policymakers must assess the costs and benefits of allowing for problem correction through the natural operation of market mechanisms. This assessment involves the policymakers' considerations of society's ability to tolerate certain risks or society's desire to uphold certain moral standards. If the time lag poses risks that policymakers decide are morally unbearable, then more restrictive remedies (including banning the product) may be endorsed.

In sum, when a positive interaction occurs, the actions of informed consumers improve the lot of uninformed consumers. However it is equally possible that informed consumers' choices may stimulate the market in ways that are detrimental to other consumers' welfare. For example, informed consumers' demands for more information may result in information remedies requiring additional cognitive effort and search costs for average consumers [Bettman 1975; Jacoby 1974]. Similarly, because activist consumers are not representative of all consumers, government and firm actions to meet their demands may be inappropriate [Moyer 1984; Wally, Dickey and Talarzyk 1977]. Therefore, policymakers should be careful to anticipate and assess how policy remedies aimed at facilitating positive interactions affect uninformed and nonactivist consumers. The next two sections de- 
Negative Consumer Segment Interaction Patterns

\section{When Products and Programs Targeted for Some Consumers Adversely Affect Other Consumers}

Policy Considerations scribe how differences among consumer segments can affect the likelihood of incomplete and negative interaction patterns.

A negative interaction implies that what benefits one consumer harms another or adversely affects their choices. Negative interactions may result from: 1) firm or government programs and products targeted for one consumer segment that spill over to harm another segment; or 2) consumer choices that spill over to harm others who do not choose (e.g., third-party effects). Negative interaction patterns raise complex issues about how to trade off benefits to some consumers against harm to others. A discussion of the two kinds of negative interaction patterns as they relate to policy remedy choices follows.

Consumers exhibit different levels of awareness and comprehension of product information and product risks. These differing levels of attention and comprehension may mislead consumers to buy the product and incur harm (i.e., increase their materiality) [Beales, Craswell and Salop 1981]. When these differences are not accounted for in government and firm activities, negative interactions are likely to occur. Craswell [1985] argues that virtually all advertising can be viewed as misleading for some consumers and informative for others.

In product safety and advertising deception judgments, the extent of negative interaction between a target market and various submarkets is of crucial importance [Ford and Calfee 1986]. An example of the complexity of assessing the interactions between consumers with differing levels of awareness and materiality is contained in the case of chain saws [Pittle 1988]. Chain saws are plagued by a "kickback" problem and most manufacturers provide clear instructions to purchasers about the problem. However, kickback accidents still occur about 23,000 times a year, presumably because many consumers do not read the instructions or fail to understand or follow them. In this case, although many liability suits are brought, no chain saw distributor has been successfully sued. One market restraint remedy, mandating the inclusion of a safety tip at the end of the saw, would greatly reduce the number of accidents that occur. However, the tip also reduces the effectiveness of the chain saw. In this case, by either allowing the product to remain as is or using a market restraint remedy, a negative interaction occurs. In the first case, the informed consumer benefits and the uninformed does not; in the latter case, the imposition of the product standard penalizes the informed consumer segment who reads and follows the instructions.

When sellers or the government offer information or products that are desired and useful for the target segment, yet may have detrimental effects on other portions of the market, policy remedy decisions can take three forms: 1) segment isolation, 2) segment education or 3) market restraint.

Segment isolation may be accomplished in two ways. First, consumers could be allowed to screen themselves. This would imply that firms do a better job of letting target consumers know who should listen to their messages and/or who should buy their products. For example, when manufacturers attempt to restrict toy usage or movie viewing to specified age groups, consumers are being allowed to screen themselves or their children from potential harm.

Second, vulnerable submarkets could be restricted from having access to potentially misleading information and/or potentially harmful products (e.g., restricting where information is published and products are distributed). These restrictions must be undertaken with considerable caution because the possibility for discrimination exists (see our discussion of discrimination in the section on incomplete interactions). As an example, suppose economically disadvantaged consumers suffer substantial injury because they misuse kerosene and other 
space heaters. However, if used correctly, these products are quite safe and benefit consumers by reducing their heating costs. If a segment isolation strategy were selected and these consumers were not allowed to purchase certain types of heaters, the fairness of the remedy could be questioned because it restricts one segment's right to choose. Moreover, even when discriminatory effects are deemed acceptable, it may be extremely difficult and expensive to restrict communication and/or product distribution to targeted consumers.

Another general strategy for alleviating negative interactions is to educate the harmed segment. Education remedies, in this case, may involve collecting and presenting information to these consumers to help them minimize the threat of present and future harm. Consumer eduction classes, neighborhood groups, and other informal means of increasing the knowledge and skill level of these consumers may be effective. Planned change programs have successfully used educationally strategies when the objective is to heighten awareness of a problem and its solution, but also suggest change will not occur unless the target group is also highly motivated [Zaltman and Duncan 1977]. Planned change research also recommends that information disseminated to educate consumers should be channelled through the gatekeepers and influential members of the harmed segment. Barriers to successfully using education strategies exist when the harmed segment has no formal education, is geographically dispersed, and is resistant to the idea of self-help.

If, however, segment isolation or education strategies are not successful in reducing negative spillovers among segments, it may be necessary to restrain the market by prohibiting information or the product altogether. An especially dramatic example of this problem is infant milk formula distribution to underdeveloped countries [Post 1985; Post 1986; Post and Baer 1978]. ${ }^{12}$ Experience has shown that elite consumers in these countries can effectively use the milk formula without difficulty and derive many medical advantages from its distribution. However, mass distribution of the formula has proven dangerously ineffective because most consumers lack clean water and the education to use the formula correctly. These negative interactions resulted in the World Health Organization putting forth the International Code of Marketing Breast Milk Substitutes restricting the nature of these marketing activities in underdeveloped countries. ${ }^{13}$ In this case, market restraint has the attendant problem of creating negative repercussions for the informed segment. That is, because certain consumers misuse the product, access is restricted for everyone.

Similar situations now exist in Third World countries as hazardous pesticides and unsafe pharmaceuticals enter these uninformed and unregulated markets [Reich 1988]. In these cases, a variety of political, economic, social, and cultural factors increase the difficulty of distributing and promoting products to only that portion of the population (either within or between countries) who can safely use the products [Silverman 1976; 1982]. This difficulty increases dramatically outside the U.S. where very effective, informal means of distribution often operate to undermine safe and conscientious distribution. Moreover, negative interactions are more likely because segment differences are often greater and based on a greater number of dimensions (e.g., education, language, experience, culture). In these situations, market restraint remedies might be more appropriate than either a segment isolation or education strategy.

When the Choices of Some Consumers Affect Other Consumers Who Do Not Choose
A different kind of problem occurs when the choices of one consumer adversely affect other consumers who do not choose. There are numerous examples of this problem (e.g., parents' choices affect their children, smokers' choices affect nonsmokers, drunk drivers' choices affect sober drivers ) [Dardis 1980]. The problem is one of some consumers' self-serving choices spilling over to affect other indi- 
viduals in ways that they or others perceive as unacceptable. ${ }^{14}$ This perception follows from the individuals' beliefs that a specific mode of conduct or end-state of existence is preferable to other modes or end-states [Rokeach 1973, p. 5]. We use the term "value conflict" to describe these differences in their beliefs [Buchholz 1985].

When individual values diverge and negative interactions result, there is market inefficiency because the cost of a good to one individual is less than the cost of a good to another or to society. The cost-benefit approach tries to resolve this problem by creating policy that sets the good's market price equal to its social price. To calculate this social price, policymakers assess the expected value of harm imposed on some consumers by others' self-serving choices [Arrow 1977]. This approach is fraught with the difficulties of assigning market values to social costs and benefits. For example, under a strict Pareto improvement criteria, regulators would value low income lives less than higher income lives. However, this runs counter to our beliefs about equality, especially if the poorer person has not willingly assumed a particular risk [Crandell 1988, p. 68]. ${ }^{15}$ Thus, cost-benefit analysis makes implicit judgments about what is fair and just for different members of society.

This paper suggests that policymakers explicitly include issues of fairness, justice, and equity in their policy choices. Doing so raises tough questions about the value of life and what is acceptable and unacceptable risk [Fischoff et al. 1981]. However, we agree with Crandell [1988] who argues that too much time has been spent debating the value of life and making assessments of risk, and not enough attention has been given to the choice of policy remedies when individual values conflict.

A second policy approach that holds promise for long-term, cost-effective resolution of value conflicts is one that motivates consumers affecting others to voluntarily incorporate them into their utility functions [cf., Lynne and Oldenquist 1986]. Velasquez [1982] stresses the importance of this approach when he points out that, "a society's system of moral standards will identify situations in which each person must restrain his or her self-interest in order to secure a system of conduct that is mutually advantageous to everyone" [p. 11]. This approach represents an optimal policy objective because it allows individuals to exercise their freedom of choice without harming fellow consumers and it is consistent with policymakers' preference for less interference in marketplace activities. Thus, some of the most important issues in regulating negative interactions may center on identifying critical factors that facilitate this objective. Three issues that take on particular significance in this regard are: consumers' connectedness or relatedness, the nature of value commitments, and the costs of changing behavior.

Some theory and research has focused on the importance of consumer connectedness in motivating altruistic behavior [cf., Batson, in press; Clark 1984; Lerner 1982; Oldenquist 1982]. We have identified three subfactors affecting consumers' perceptions of their connectedness to others: 1) blood relationship; 2) emotional proximity or closeness (e.g., friendship) and; 3) spiritual or religious convictions (e.g., We are one in the Father). Consumers will display their connectedness to others relative to the degree that they display these types of relationships or hold these types of convictions. As Rescher [1983] notes:

. . . human nature being what it is, we so operate in the context of our personal affairs as to value the interests of people differentially, varying with their proximity to or remoteness from us: be they relations, friends and neighbors, colleagues and acquaintances, fellows who share some professional or cultural affinity, or "perfect strangers" with whom we have little or nothing in common [p. 160]. 
Therefore, connectedness can provide the rationale for incorporating others into one's preferences. Future research should be directed at understanding these factors and how they affect the degree to which consumers have concern for others.

The second factor influencing whether an individual incorporates others into his/her decision-making is the nature of certain value commitments. This can occur in two important ways. First, if consumers believe that committing a particular behavior upholds or negates something they value, it will more than likely affect their interactions with other consumers. For example, if a smoking consumer values the freedom of choice, it is likely that they will resist restricting their behaviors to benefit others [Frank 1987]. Second, the presence of one specific value-the caring for others at the expense or sacrifice of individual gain may be an important determinant of remedy choice.

A final factor affecting the inclusion of others in decision-making is the consumers' costs of altering their choices and behaviors. These costs may include, among others, the monetary, emotional, and time expenditures of searching for and adopting alternative behaviors or choices, and changing habits. The cost of changing behaviors is largely affected by the amount of change required. As two consumers' value differences increase, the costs to either of them of changing their choices to accommodate the other also increases. ${ }^{16}$ If incorporating the preferences of others incurs few costs, then even relatively remote, unconnected others may be included.

Examples may help clarify how policy remedies are chosen to ameliorate value conflicts using these principles. Consider the cases of the smoking pregnant woman and the smoking co-worker. In both cases, there exists a value conflict problem-the mother affecting her child and the co-worker affecting his/her colleagues in ways that may harm them. It is more likely that the smoking pregnant woman has stronger measure of connectedness to her child than the smoking coworker has for his/her colleagues. Therefore, there is a high probability that the mother can be motivated to incorporate the effect on her child and stop smoking. As a result, information and education remedies should be effective in remedying the situation including the use of warning labels describing how "low fetal birth weights" can result from smoking, advertisements, and pamphlets distributed through obstetricians and hospital education programs.

The case of the smoking co-worker has had different policy outcomes. In major cities all over the United States, policymakers are deciding that the health risks posed by smokers are high and their consumption behaviors should be restricted. To remedy the problem, many cities are passing public health regulations forbidding smoking in public places, including places of employment, or relegating smoking to designated areas. Because of the lower degree of connectedness and the perceived high costs to the smoker of voluntarily accommodating the nonsmoker, policymakers appropriately decided there was a low probability of information remedies working, and more restrictive remedies were selected.

As these examples suggest, negative interactions and the value conflicts that create them bring policymakers up against some of the most difficult issues in social choice and interpersonal comparisons of utility. ${ }^{17}$ These issues include whether to uphold the freedom to make choices that impact others in negative ways and when and to what extent policy should protect those who are negatively affected by others. In considering remedies for this type of interaction, policymakers need to be aware that they are making statements about society's objectives and moral standards. Moreover, this analysis suggests that for the broad spectrum of value conflict problems, policy remedy choice should consider assessments of consumer connectedness, the nature of consumer value commitments and the costs to offending consumers for changing their behaviors. These 
Incomplete Interaction Patterns and Isolated Consumer Segments questions and their implications go well beyond cost-benefit analysis and suggest a radically different perspective on consumer policy choice. ${ }^{18}$

In this section we investigate the antecedents to and consequences of consumer isolation in the marketplace. Segment isolation describes situations where the actions of one segment of consumers or government and/or firm activities directed to one segment of consumers do not spill over to affect other segment(s). ${ }^{19} \mathrm{We}$ do not reconsider the benefits of incomplete interactions and isolated consumers discussed as a policy remedy to negative interactions, although isolation created to ameliorate harm can also have discriminatory implications. Instead we focus on cases where the benefits of market efficiency do not accrue to consumers because they are isolated.

Several researchers have noted factors that inhibit the benefits received by one segment from accruing to other segments or from one segment to other segments [cf., Andreasen 1977; Png and Hirschleifer 1986; Salop 1977; Salop 1986; Telser 1965]. These factors are summarized as: 1) heterogeneous abilities or characteristics; 2) heterogeneous environments; and 3) heterogeneous preferences. All three factors are potential causes of isolation because they inhibit information flows among consumers and sellers are able to differentiate among consumers on their basis. Once this differentiation has occurred, it is possible for sellers to discriminate among consumers providing differential prices, services, or even product access. We will define discrimination and comment on its market effects following a discussion of three factors that may result in consumer differentiation.

One of the most powerful bases for inhibiting the diffusion of benefits among consumer segments occurs when markets are separated by personal characteristics such as the wealth of the purchasers. For example, early research demonstrated that "ghetto consumers" paid higher prices for goods than suburban shoppers [cf., Caplovitz 1967; Sturdivant 1968; Wimmer 1981]. Other distinguishable consumer characteristics, in addition to the standard array of socioeconomic, race and gender characteristics, can lead to isolation. The FTC [1979] includes the elderly with a hearing loss, balding men, and non-English speaking shoppers as examples of consumers who may be vulnerable because of their special characteristics.

Second, environment heterogeneity or the characteristics of shopping environments combined with a consumers' lack of mobility can lead to isolation. Considerable research has suggested that by force of psychological and physical mobility barriers, many consumers shop in fragmented, deteriorated, overpriced and understocked geographic markets with narrower assortments [cf., Andreasen 1971; Cox 1969]. Unfortunately, if informed consumers shop in different markets than isolated consumers, informed choices may not be reflected in the isolated markets [Andreasen 1976].

Finally, consumer isolation may not result from buyer characteristics or merchant exploitation, but rather, very different preferences [Sowell 1981]. Preference heterogeneity describes variations across consumers' tastes and preferences [Dickson and Ginter 1987; Price, Feick and Higie, forthcoming]. Andreasen [1975] supports the notion of preference heterogeneity as being a cause of consumer isolation, over and above buyer characteristics. Andreasen also states that it is a common fallacy to assume that isolated consumers are like other consumers except they have less income, less education, larger families and so on. He notes these consumers' special characteristics result in special problems such as unstable income, different tastes and preferences, powerlessness, and need for social gratification. These problems, in turn, can cause informed consumer and isolated consumers to shop different markets leading to the same market separation that 
would be implied by physically distant markets (see Phlips [1983] and Schwartz and Wilde [1982; 1985] for discussions of markets differentiated by quality). For example, certain low quality retailers and products may be exclusively preferred by uninformed consumers, and hence not benefit from the policing and diffusing activities of informed consumers.

Any time consumers can be differentiated on the basis of heterogeneous characteristics, environments, or preferences, the opportunity exists to discriminate, i.e., to make a distinction in favor or against one person as compared with another. Sellers can discriminate between segments of consumer in the provision of product-related services, access to products, or pricing. For example, the better dressed gentleman may receive better service, children are not allowed into certain movies, and the poor or uninformed consumer may pay more.

Discrimination is a ubiquitous phenomenon. It is neither good nor bad, but it always raises issues of market inequities and inefficiencies. One significant form of discrimination used against isolated segments is price discrimination. Price discrimination exists when two varieties of a commodity are sold to different consumers at different net prices where the net price is corrected for the cost associated with product differentiation [Phlips 1983].

We focus on two types of price discrimination: preference-based and characteristic-based. Preference-based price discrimination occurs when consumers are charged a premium for their preferences, often unjustified by cost differences. For example, business travellers who choose not to stay over Saturday night, consumers who prefer name brand clothing, and consumers who prefer the convenience of credit cards over lower-interest loans. In contrast, examples of characteristicbased price discrimination include selling Disneyland entrance tickets at a discount to senior citizens, children or military personnel, or using a sliding scale based on customer income to price medical services.

In many cases price discrimination is used to cross-subsidize various consumer groups (e.g., wealthier patients pay more to subsidize poorer patients). Although this practice remains controversial and raises serious equity issues, some research provides support for the practice in terms of improved social welfare [Crompton and Lamb 1986; Sawhill 1988]. In many other cases, discriminatory practices are designed to take advantage of consumer isolation in such a way as to differentially worsen their outcomes with no offsetting gain to other consumers in the marketplace. Several illustrations are discussed.

Merchants able to differentiate among consumers on any of the dimensions described above can systematically discriminate against them by using tactics that meet their special needs or circumstances. For example, Andreasen [1975] notes the special susceptibility of low income consumers to certain low price tactics, free gimmicks and fear appeals. Sellers exploit this susceptibility by employing these tactics in places shopped by predominantly low income consumers [Caplovitz 1974]. While some of these practices are perfectly legal, they are simply not effective when used with informed consumers. Other seller practices may be of questionable legality or illegal, but because consumers are not policing these markets, the practices may go undetected. ${ }^{20}$

Consumers can also be discriminated by their cost of information [cf., Jeuland and Narasimhan 1985; Rosenthal 1980; Shilony 1977; Varian 1980]. One common seller tactic used is the offer to "match" or "beat" a competitor's price. This seller mechanism systematically discriminates between informed and uninformed buyers and at the extreme may drive prices to monopoly levels [Plott 1981; Png and Hirschleifer 1986; Salop 1977; Salop 1986]. Using this mechanism, a seller can set a high list price for uninformed buyers, but still retain informed buyers through offers to match price. Salop [1977] has described this type of discrimination as creating a two-price equilibrium in the marketplace with knowledgeable consum- 
ers paying one price and unknowledgeable or uninformed consumers paying another.

Informational price discrimination is troublesome because research has demonstrated that most consumers perform very low levels of search [Meier 1985; Price et al. 1987]. Hence, business practices to take advantage of informationally separate markets can have profound, distorting effects on price-quality offerings in the market [Schwartz 1977]. For example, prescription drug price disclosures for the same quality drug were reported to be as much as five times that charged by another druggist in the same community [Federal Trade Commission 1979].

Policy Considerations A major implication of incomplete interactions is that policymakers can not rely on information remedies that target the informed consumer segment. With incomplete interactions, the benefits of the information sensitive consumers' search, choices, and complaints do not spill over to isolated segments [Schwartz and Wilde 1985].

Two general strategies might be pursued by policymakers faced with isolated consumer segments (see Table 1). One strategy is to find ways to complete the network of interactions between informed and isolated consumer segments. We identify three approaches to increasing interactions among consumers. First, sellers can be offered incentives to treat markets as if they are common. Theory holds that if incentives are offered to at least some sellers who treat the markets as if they are common, the effects of discriminatory tactics of other sellers will deteriorate [Phlips 1983]. For example, retailer subsidies to operate in ghetto areas may have the effect of driving unscrupulous retailers to change their tactics or go out of business. Although the approach holds promise and wide appeal, more work is needed to demonstrate feasible implementations of incentive programs [Gamse 1982].

Another means of completing the network of interactions between segments is to offer consumers incentives to treat markets as if they were common. Isolated consumers could be encouraged to shop the same retailers as informed consumers by increasing their physical mobility through incentives such as free buses to non-ghetto shopping areas. Although these incentives may eliminate certain barriers to common markets, other barriers (such as monetary constraints that force these consumers to shop low-quality markets) are likely to remain.

Finally, interactions between informed and isolated consumer segments could be increased by facilitating forums for consumer communications. For example, if informed consumers made public the "low price" paid in a local market then the seller "match price" discrimination mechanism could be circumvented. Because information sensitive consumers are often motivated by a desire to police the market [Thorelli and Engledow 1980; Thorelli and Thorelli 1977], easily accessible forums for buyer information exchange could reduce the effectiveness of at least some mechanisms for buyer discrimination [Maynes, Morgan, Vivian and Duncan 1977]. A number of independent information providers do exist in the United States and Europe to provide such a forum [Murphy and Ross 1987; 1986]. Most do not provide local market information and so have restricted applicability to some of the problems of discrimination just discussed. However, recent services such as Washington Consumers' Checkbook and the Bay Area Consumers' Checkbook combine local price and product quality information [Hartjens 1983; Ippolito 1988].

When differing preferences are the cause of consumer isolation, it may be difficult to facilitate common markets. This is true because if consumers prefer different products or different shopping areas, there is no basis for information exchange [Price, Feick and Higie, forthcoming]. In these circumstances, the general strategy should be to reduce discrimination against the isolated consumer 
segments. Two approaches might be used. First, policy might be directed at creating an informed consumer group within the isolated segment to increase the likelihood of subsequent positive interactions. ${ }^{21}$ An experiment performed in Europe found that providing consumers with subscriptions to the German version of Consumer Reports actually turned them into "information seekers" who made greater use of all kinds of information sources [Kaas and Tolle 1981; Olander 1988].

Over the long-term, consumer education programs and consumer activist groups may serve to circumvent seller discrimination tactics by creating a policing group within the isolated segment. However, in the short term, a second approach based on more restrictive remedies may be required. This second approach would be directed at identifying and circumventing seller discrimination tactics. As one illustration, sellers who offer to match price might be required to disclose information about variability in prices obtained by all buyers (i.e., message remedies). Or sellers may be restrained from certain types of practices. On a cautionary note, however, the imposition of remedies at odds with the special circumstances and preference functions of these groups may simply drive exploitive merchant practices underground (e.g., loan sharks, etc.) [Andreasen 1975].

In general, the greater the gap between informed and uninformed consumers' characteristics, environments, and preferences, the greater the potential to discriminate and the more likely that market restraint remedies will be required. When viewed on both a national and global scale, surmounting the problems of discrimination in isolated segments through information and education seems virtually impossible at least in the short-term. Several researchers have argued that as consumers are unable to protect themselves via information and education, market restrain remedies should become a policy priority, if product-related accidents are to diminish [Allain 1988; Kinsey 1988; Reich 1988; Singer 1975].

Conclusions This paper proposes a framework for analyzing consumer and market problems and policy remedy choices in terms of interactions or spillovers among consumer segments. An important distinction between this approach and previous theory and research is the recommendation that remedies should be evaluated on their ability to facilitate or overcome these interaction patterns. This approach encourages a consumer segment orientation over a total market effects orientation; this suggesting that policymakers scan the marketplace for evidence of isolated segments and segments receiving negative repercussions from policy actions that transform the marketplace in otherwise positive ways.

By suggesting policy alternatives for positive, negative, and incomplete consumer segment interactions, this paper goes beyond past efforts. Past efforts provide only descriptive analyses of incomplete interactions (e.g. "disadvantaged" consumers living in depressed markets) and focus very generally on negative interactions. However, because policymakers must have the ability to arbitrate and resolve these problems, this paper attempts to understand the antecedents to and consequences of negative and incomplete segment interactions. We argue that policymakers should systematically assess what type of interaction patterns exist and then consider ways of manipulating that pattern by channeling remedies through that pattern to affect desired outcomes.

This paper posits that research on aggregate costs and benefits needs to be complemented by research on the distributional consequences of regulation. Most fundamentally, we argue that these distributional consequences are often outcomes of particular patterns of consumer interactions. As Harrison [1981] notes, “... while aggregate efficiency analyses may form the bedrock of economic analyses for regulatory policy, distributional analyses constitute an important, and 
somewhat neglected complement" [p. 196]. Research into interaction patterns and distributional effects makes several major contributions. First, such research decreases obstacles to efficient and effective regulations. For example, it could identify seller tactics that serve to separate and discriminate markets. Second, this research allows policymakers to promote equity in situations where it is important to do so. For example, if policymakers decide to act as a vanguard for isolated consumers, then analyses of interaction patterns and their distributional consequences is critical because it allows the measurement of harm both within and across consumer segments and suggests mechanisms for understanding differing market benefits or costs accruing to informed and isolated segments.

Third, distributional effects research could be used to avoid significant unintended effects of regulation on the performance of the economic system. For example, information programs, in certain cases, could further separate segments of the market or lead to negative interactions among consumers, thereby worsening the circumstances of large numbers of consumers. Therefore, this framework makes clear how consumer and market problems will be affected by different policy remedies. As a result, we do not adhere to any one remedy as the only answer to consumer problems, but examine a wide range of policy options for a wide range of consumer and market problems. Therefore, this approach reveals the weaknesses, paradoxes, and fallacies certain policy approaches and decisions may have for both market efficiency and consumer welfare.

Despite the potential contributions of this approach to policy remedy selection and implementation, there are major obstacles to its use. Importantly, it imposes large data requirements on regulatory agencies and complicates rather than simplifies policy remedy choice. Another barrier lies in the fact that policy decisions are currently made by different regulatory bodies with different agendas and at least historically, a distinct set of remedy options available for their use. Perhaps a deeper analysis of the distributional effects of policy remedies will reveal the need for a greater mix of alternatives to be made available to a variety of regulatory bodies.

At a more subtle level, this approach imposes another cost. It requires policymakers to abandon two comfortable illusions. One of these illusions is that costbenefit judgments are economic and not political or social. This paper suggests that aggregate cost-benefit analysis may differentially impact various segments of consumers with political and social repercussions.

Another illusion that policymakers must abandon is that the invisible hand of the market, when set into motion with market incentive-based government intervention, will correct market failure. ${ }^{22}$ As this paper suggests, market incentive-based government intervention may have limited effects when the market consists of negative and incomplete interactions. These market conditions require a more comprehensive segment by segment assessment of an intervention's effects. By moderating reliance on the market mechanism, policymakers will be forced to consider the characteristics of each intervention, the market conditions, and the interactions among individual consumer segments. These considerations will paint a richer and more realistic picture of policy effects.

From the policymaker's perspective, the scope of this paper is fairly narrow. For example, we do not address seller issues in remedy selection and implementation, including issues of incentive compatibility and cost structure [cf., Mazis et al. 1981]. Distributional effects of regulation may also unintentionally change the competitive advantages of firms and alter the structure and performance of an industry [Mitnick 1981]. And although the distributional analyses proposed in this paper are designed to complement, rather than to replace aggregate cost-benefit analyses, we provide only cursory references to a total market effects orientation, focusing instead on where such an orientation is insufficient as a basis for policy 
remedy choice. Furthermore, the myriad of political issues within regulatory bodies that guide policy remedy choice and implementation are not here addressed [Wilson 1980]. Nor does this paper discuss any policy remedy in detail, deliberate their pros and cons, or investigate remedy options in light of consumer processing limitations. ${ }^{23}$ Instead, this paper seeks to understand the complexity of policy remedy choices in light of consumer segment interactions and their distributional consequences.

Notes 1. Market failure is used to describe a breakdown of the self-regulating properties usually ascribed to the market mechanism [Elster 1986]. For a more complete discussion of types of market failure see the Federal Trade Commission Report on Consumer Information Remedies [1979]. For an interesting discussion of the limitations of the market failure concept see Bartlett [1978].

2. We acknowledge that although economists have incorporated distributional considerations into cost-benefit analysis (e.g., public project selection [McGuire and Garn 1969]), these issues have not been addressed specifically in the context of consumer policy.

3. The term externalities might also be used to describe consumer interactions. An externality exists whenever consumption by one person affects consumption by another person. We prefer the term interaction because it focuses on the dynamics of consumer relationships, is not restricted to consumption-based interactions, and does not imply that externalities exist outside of the system [as the term "extemalities" seems to].

4. These rights include the right to safety, the right to be informed, the right to choose, and the right to be heard [redress]. These rights are the foundation for business and government policies designed to protect consumers' interests [Engel, Blackwell and Miniard 1986].

5. Antitrust policy, which may be a response to market structure inadequacies resulting in market failure, is not included in this framework. Moreover, the range of potential national responses to the problem of negative externalities between countries (such as import barriers) is not addressed systematically. However, this framework can be extended to incorporate consumer problems that arise because of flows between nations.

6. This argument is elaborated in a discussion by Farris and Albion [1980] concerning the relationship between advertising and information.

7. The terms interaction and spillover are used interchangeably throughout this paper. Other typologies of interaction patterns are, of course, possible. For example, one reviewer noted that consumers could be divided into two groups: those who value information and those who, for one reason or another, do not. However, because many of the negative interactions described in this paper are consumption rather than information based, we chose not to adopt this framework.

8. The free-rider problem resulting from the public good status of information can also be a source of market failure implying that too little product information will be produced (see Salop [1976] for a discussion).

9. The required ratio of informed to uninformed consumers depends upon a myriad of other factors such as market-cost structure, consumer preferences for quality and total demand for the product or service [Schwartz and Wilde 1985].

10. It could be argued that policymakers have "learned" that the market mechanism often operates quite efficiently when some fraction of the population stays informed and makes wiser choices. Although many programs were not designed with that objective, many contemporary programs have that effect.

11. Often sellers will assist in creating this informed segment by drawing consumers' attention to unbiased third party information that favorably evaluates their products or services. For example, Calfee and Ford [1988] discuss a series of ads used by General Motors focusing on safety statistics produced by the Insurance Institute for Highway Safety.

12. In this and other international cases, interactions between countries are viewed as comparable to interactions between segments within a country.

13. Regarding this and other global cases, Allain [1988] makes an especially important point: "It is impossible to separate the problems of consumers in developing countries from those in industrialized countries. Many problems have their origins in products, services, or habits that 'travel' 
via international trade from industrialized countries to the rest of the world. Their solution requires cooperation by consumer organizations in all countries and by all governments" [p. 509]. Allain also describes the critical role the International Organization of Consumers Union plays in the protection of consumers in underdeveloped countries.

14. This analysis is also applicable to the mistake of treating the consumer and the buyer as synonymous. Increasingly, the consumers who need product safety are not buyers but the users of a product somebody else bought [Nelson 1988].

15. Schwartz [1977] provides a detailed description of the legal standard for unfairness and its incorporation of issues such as "offending public policy."

16. To the extent that consumers value very different things their ability to understand, or empathize with one another is also likely to decrease. For a discussion of the important role of empathy in altruistic behavior see, for example, Batson et al. [1983] and Krebs [1975].

17. It is not the purpose of this paper to review the burgeoning literature on social choice, or to oversimplify the complexity of these problems. Excellent reviews of the social choice literature are available elsewhere [cf., Elster and Hylland 1986; Pattanaik and Salles 1983; Plott 1976; Sen 1985].

18. It should be noted that if a risk is viewed as sufficiently onerous, such that the costs to society clearly outweigh the benefits to the individual, policy remedies are likely to take a restrictive bent, regardless of the relative effectiveness of information remedies. Alternatively, if the risk is viewed as low, such that the benefits to the individual appear to outweigh the costs to society, information remedies may be employed despite a low probability of effectiveness.

19. In his work, Andreasen does not use the term "isolation." However his discussion of "disadvantaged" consumers is highly appropriate for dealing with consumer isolation. Being "disadvantaged" in Andreasen's terminology is a form of consumer isolation.

20. Andreasen [1986] summarizes the current stance of the FTC as one that presumes consumers can detect exploitation and will act on the information. Unfortunately, it is relatively well documented that the disadvantaged are both less likely to detect mistreatment and even when they detect mistreatment they are less likely to complain [Andreasen 1986, p. 123].

21. A potential irony of this approach is that, if successful, education may change their preferences and circumstances sufficiently that they leave geographic markets they are being educated to correct. Isolated consumers targeted with consumer education programs are also likely to be the targets of other education and job training programs designed to move them out of geographic markets. This may serve only to worsen the lot of those that remain (see Andreasen [1975] for a discussion of this problem).

22. Hirschman [1970] describes the ultimate failing of the invisible hand of the market without other mechanisms for market outcome adjustment. In this context, he describes consumer activism and other political actions [i.e., voice].

23. The interested reader is referred to the Federal Trade Commission Report on Information Remedies [1979], pp. 75-110, 184-315.

References Allain, Jean-Pierre (1988), "Consumer Organization and Representation in Developing Countries," The Frontier of Research In The Consumer Interest, ed. E. Scott Maynes and ACCI Research Committee, Columbia, MO: American Council on Consumer Interests, 506-09.

Anderson, C. Dennis and John D. Claxton (1982), "Barriers to Consumer Choice of Energy Efficient Products," Journal of Consumer Research, 9 (September), 163-70.

Andreasen, Alan R. (1986), "Disadvantaged Consumers in the 1980s," The Future of Consumerism, eds. P.N. Bloom and R. Belk Smith, Lexington, MA: Lexington Books, 113-28.

(1976), "The Differing Nature of Consumerism in the Ghetto," Journal of Consumer Affairs, 10 (Winter), 179-90.

(1975), The Disadvantaged Consumer, New York: Free Press.

(1971), Inner City Business: A Case Study of Buffalo, New York, New York: Praeger Publishers, Inc.

Arrow, Kenneth J. (1977), "Extended Sympathy and the Possibility of Social Choice," American Economic Review, 67 (February), 219-25. 
(1978), "Marketing Ideologies: The Influencing of Social Values," paper presented at American Economics Association Meetings, Chicago: IL, August.

Bardach, Eugene and Robert A. Kagan (1982), Going By the Book, Philadelphia: Temple University Press.

Batson, C. Daniel (in press), "Prosocial Motivation: Is It Ever Truly Altruistic?" in Advances in Experimental Social Psychology, ed. L. Berkowitz, New York: Academic Press.

Karen O'Quin, Jim Fultz, Mary Vanderplas and Alice Isen (1983), "Influence of Self-Reported Distress and Empathy on Egoistic Versus Altruistic Motivation to Help," Journal of Personality and Social Behavior, 45 (3), 706-18.

Beales, Howard, Richard Craswell and Steven Salop (1981a), "The Efficient Regulation of Consumer Information," Journal of Law and Economics, 24 (December), 491-539.

—, _ and (1981b), "Information Remedies for Consumer Protection," American Economic Review, 71 (May), 410-13.

Research, Vol. 7, ed. Jerry C. Olson, Ann Arbor, MI: Association for Consumer Research, 238-40.

Beauchamp, Tom L. and Norman E. Bowie (1983), Ethical Theory and Business, Englewood Cliffs, N.J.: Prentice-Hall Inc.

Bellah, Robert N., Richard Madsen, William M. Sullivan, Ann Swidler, and Steven Tipton (1985), Habits of the Heart: Individualism and Commitment in American Life. Berkeley: University of California Press.

Bettman, James R. (1975), "Issues in Designing Consumer Information Environments," Journal of Consumer Research, 2 (December), 169-77.

John Payne and Richard Staelin (1986), "Cognitive Considerations in Designing Effective Labels for Presenting Risk Information," Journal of Public Policy and Marketing, 5, 1-28.

Breyer, Stephen (1982), Regulation and Its Reform, Harvard University Press: Cambridge, MA.

Bucholz, Rogene A. (1982), Business Environment and Public Policv, Englewood Cliffs, N.J.: PrenticeHall, Inc.

Bucklin, Louis P. (1974), "The Uniform Grading System for Tires: Its Effect Upon Consumers and Industry Competition," The Antitrust Bulletin, 14 (Winter), 783-801.

Calabresi, Guido and A. Douglas Melamed (1972), "Property Rules, Liability Rules and Inalienability: One View of the Cathedral," Harvard Law Review, 85, 1089-1128.

Calfee, John E. and Gary T. Ford (1988), "Economics, Information and Consumer Behavior," in Advances in Consumer Research, Vol. 15, ed. Michael J. Houston, 234-38.

_ and - (1985), "The FTC's Product Defects Program and Consumer Perceptions of Product Quality," in Perceived Quality: How Consumers View Stores and Merchandise, eds. Jacob Jacoby and Jerry C. Olson, Lexington, Massachusetts: Lexington Books, 175-91.

Caplovitz, David (1967), The Poor Pay More, New York: The Free Press.

Capon, Noel and Richard J. Lutz (1979), "A Model and Methodology for the Development of Consumer Information Programs," Journal of Marketing, 43 (January), 58-67.

- and (1983), "The Marketing of Consumer Information," Journal of Marketing, 47 (Summer), 108-12.

Clark, Margaret S. (1984), "Record Keeping in Two Types of Relationships," Journal of Personality and Social Psychology, 47 (3), 549-57.

Cox, William E., Jr. (1969), “A Commercial Structure Model for Depressed Neighborhoods," Journal of Marketing, 33 (July), 1-9.

Crandell, Robert W. (1988), "The Use of Cost-Benefit Analysis in Product Safety Regulation," The Frontier of Research In The Consumer Interest, ed. E. Scott Maynes and ACCI Research Committee, Columbia, MO: American Council on Consumer Interests, 61-76.

Craswell, Richard (1985), "Interpreting Deceptive Advertising," Boston University Law Review, 65 (July), 658-732.

Crompton, John L. and Charles W. Lamb (1986), Marketing Govermment and Social Services, New York, N.Y.: John Wiley \& Sons.

Daly, George, and David W. Brady (1976), "Federal Regulation of Economic Activity," in James E. Anderson, ed., Economic Regulatory Policies, Lexington, Mass., Lexington Books, 171- 86. 
Dardis, Rachel (1980), "Economic Analysis of Current Issues in Consumer Product Safety: Fabric Flammability," Journal of Consumer Affairs, 14 (Summer), 109-23.

Day, George S. (1976),"Assessing the Effects of Information Disclosure Requirements," Journal of Marketing, 40 (April), 42-52.

_ and William Brandt (1974), "Consumer Research and the Evaluation of Information Disclosure Requirements: The Case of Truth in Lending," Journal of Consumer Research, 1 (June), 21-32.

Dickson, Peter R. and James L. Ginter (1987), "Market Segmentation, Product Differentiation, and Marketing Strategy," Journal of Marketing, 51 (April), 1-10.

Donaldson, Thomas (1982), Corporations and Morality, Englewood Cliffs, N.J.: Prentice-Hall, Inc. and Patricia H. Werhane (1982), Ethical Issues in Business: A Philosophical Approach, Englewood Cliffs, N.J.: Prentice-Hall, Inc.

Dunn, Donald A. and Michael L. Ray (1980), "A Plan for Consumer Information System Development, Implementation and Evaluation," in Advances in Consumer Research, Vol. 7, ed. Jerry C. Olson, Ann Arbor, MI: Association for Consumer Research, 250-54.

Elster, Jon (1986), "The Market and the Forum: Three Varieties of Political Theory," in Foundations of Social Choice Theory, eds. Jon Elster and Aanund Hylland, New York, N.Y.: Cambridge University Press, 103-32.

- and Aanund Hylland (1986). Foundations of Social Choice Theory, New York, N.Y.: Cambridge University Press.

Farris, Paul W. and Mark S. Albion (1980), "The Impact of Advertising on the Price of Consumer Products," Journal of Marketing, 44 (Summer), 17-35.

Federal Trade Commission (1979), Consumer Information Remedies. Washington, D.C.: U.S. Government Printing Office.

Feick, Lawrence F, Robert O. Herrmann, and Rex H. Warland (1986), "Search for Nutrition Information: A Probit Analysis of the Use of Different Information Sources," Journal of Consumer Affairs, 20 (Winter), 173-92.

Fischoff, Baruch, Sarah Lichtenstein, Paul Slovic, Stephen L. Deby and Ralph L. Keeney (1981), "Why is it so Hard to Resolve Acceptable Risk Problems?" Acceptable Risk, Boston, MA: Cambridge University Press.

Ford, Gary T. and John E. Calfee (1986), "Recent Developments in FTC Policy on Deception," Jourmal of Marketing, 50 (July), 82-103.

Frank, Robert H. (1987), "If Homo Economicus Could Choose His Own Utility Function, Would He Want One with a Conscience?" American Economic Review, 77 (September), 593-604.

Gage, T. (1979), "The Discriminating Use of Information Disclosure Rules By the Federal Trade Commission," U.C.L.A. Law Review, 26, p. 1037.

Gamse, Roy N. (1982), "Economic Incentives", in Reforming Social Regulation, eds. LeRoy Graymer and Frederick Thompson, Beverly Hills: Sage, 159-64.

Hadden, Susan G. (1986), Read the Label: Reducing Risk by Providing Information. Boulder, CO: Westview.

Harrison, David Jr., (1981), "Regulation and Distribution," in Attacking Regulatory Problems: An Agenda for Research in the 1980s, ed. Allen R. Ferguson, Cambridge, Massachusetts: Ballinger Publishing Company, 185-208.

Hartjens, Peter G. (1983), “The Washington Consumers' Checkbook: Model for a Local System of Service Evaluation," Working Paper University of Hohenheim, Department of Consumer Economics.

Hirschman, Albert O. (1970), Exit, Voice and Loyalty: Responses to Decline in Firms, Organizations and States, Cambridge, MA: Harvard University Press.

Ippolito, Pauline M. (1988), "The Economics of Information in Consumer Markets: What Do We Know and What Do We Need to Know," in The Frontier of Research In The Consumer Interest, ed. E. Scott Maynes and ACCI Research Committee, Columbia, MO: American Council on Consumer Interests, 235-64.

Jacoby, Jacob (1974), "Consumer Reaction to Information Displays: Packaging and Advertising," in Advertising and the Public Interest, ed. Salvatore Divita, Chicago: American Marketing Association, 101-18.

- Robert W. Chestnut and William Silberman (1977), "Consumer Use and Comprehension of Nutrition Information," Journal of Consumer Research, 4 (September), 119-28. 
Jeuland, Abel P. and Chakravarthi Narasimhan (1985), "Dealing-Temporary Price Cuts—by Seller as a Buyer Discrimination Mechanism," Journal of Business, 58 (July), 295-308.

Kaas, Klaus Peter and Klaus Tolle (1981), "The Impact of Product Test Information Upon Consumers' Information Processing," Journal of Consumer Policy, 5 (Fall), 293-309.

Katz, Benjamin J. and Jane A. Rose (1976), "Information Utilization and the Awareness Criterion in Labeling Regulation," in Marketing: 1776- 1976 and Beyond, ed., Kenneth L. Bernhardt, Chicago, IL: American Marketing Association, 202-04.

Kelman, Steven (1981), "Cost-Benefit Analysis: An Ethical Critique," Across the Board, 18 (July-August), 74-82.

Kinsey, Jean (1988), "International Trade and Trade-Offs for Third World Consumers: A Matter of Entitlements," in The Frontier of Research In The Consumer Interest, ed. E. Scott Maynes and ACCI Research Committee, Columbia, MO: American Council on Consumer Interests, 397-404.

Krebs, Dennis (1975), “Empathy and Altruism," Journal of Personality and Social Psychology, 32 (6), 1134-46.

Lerner, M. J. (1982), "The Justice Motive in Human Relations and the Economic Model of Man: A Radical Analysis of Facts and Fictions," in Cooperation and Helping Behavior: Theories and Research, eds. V.J. Derlega and J. Grzelak, New York: Academic Press.

Lynn, Michael and Andrew Oldenquist (1986), "Egoistic and Nonegotistic Motives in Social Dilemmas," American Psychologist, 41 (May), 529-34.

Maynes, E. Scott and Terje Assum (1982), "Informationally Imperfect Consumer Markets: Empirical Findings and Policy Implications," Journal of Consumer Affairs, 16 (Summer), 62-87.

—, James N. Morgan, Weston Vivian and Greg J. Duncan (1977), “The Local Consumer Information System: An Institution-to-Be?" Journal of Consumer Affairs, 11 (Summer), 17-33.

Mazis, Michael and Richard Staelin (1982), "Using Information Processing Principles in Public Policymaking," Journal of Marketing and Public Policy, 1, 3-14.

_ Richard Staelin, Howard Beales and Steven Salop (1981), "A Framework for Evaluating Consumer Information Regulation," Journal of Marketing, 45 (Winter), 11-21.

McCullough, James and Roger Best (1980), "Consumer Preferences for Food Label Information: A Basis for Segmentation," Journal of Consumer Affairs, 14 (Summer), 180-92.

McCraw, Thomas K. (1984), Prophets of Regulation, Cambridge, MA: Harvard University Press.

McGuire, Martin and Harvey Garn (1969), "The Integration of Equity and Efficiency Criteria in Public Project Selection," Economic Journal, 79, 882-93.

Meier, Kenneth J. (1984), "The Limits of Cost-Benefit Analysis," in Decision Making in Public Administration, ed. Lloyd G. Nigro, New York: Marcel Dekker, 43-63.

- (1985), Regulation: Politics, Bureaucracy, and Economics, New York: St. Martin's Press.

Miller, John A. David G. Topel, and Robert E. Rust (1976), "USDA Beef Grading: A Failure in Consumer Information?" Journal of Marketing, vol 40., 25-31.

Mitnick, Barry M. (1981), “The Strategic Uses of Regulation-and Deregulation," Business Horizons, vol. 24, no. 2, 71-83.

Moorman, Christine (1988), "The Effect of Stimulus-Induced Motivation and Ability States on the Processing of Nutrition Disclosures," unpublished doctoral dissertation, University of Pittsburgh.

Moyer, Mel S. (1984), "Characteristics of Consumer Complainants," Joumal of Public Policy and Marketing, Vol. 3, 67-85.

Murphy, Patrick E. and Steven C. Ross (1987), "Evaluating Service Firms: Approaches with Policy Recommendations," Journal of Consumer Policy, 10 (December), 363-81.

- and (1986), "Local Consumer Information Systems for Services: A Test," Journal of Consumer Affairs, 20 (Winter), 249-66.

Nelson, Helen E. (1988), "The Issues in Regulation and Deregulation," The Frontier of Research In The Consumer Interest, ed. E. Scott Maynes and ACCI Research Committee, Columbia, MO: American Council on Consumer Interests, 457-61.

Olander, Folke (1988), "Salient Issues in Current European Consumer Policy Research," in The Frontier of Research In The Consumer Interest, ed. E. Scott Maynes and ACCI Research Committee, Columbia, MO: American Council on Consumer Interests, 547-83.

Olshavsky, Richard (1988), "Determinants of Information Use: Beyond the Simple Cost Benefit Model," in The Frontier of Research In The Consumer Interest, ed. E. Scott Maynes and ACCI Research Committee, Columbia, MO: American Council on Consumer Interests, 231-34. 
Oldenquist, Andrew (1982), "Loyalties," Joumal of Philosophy, 79 (April), 173-93

Padberg, Daniel (1977), "Non-Use Benefits of Mandatory Consumer Information Programs," Journal of Consumer Policy, 1, 1-14.

Pattanaik, Prasanta K. and Salles, Maurice (1983), Social Choice and Welfare, Amsterdam: North-Holland.

Pittle, R. David (1988), "Product Safety: The Views of A Former Regulator," in The Frontier of Research In The Consumer Interest, ed. E. Scott Maynes and ACCI Research Committee, Columbia, MO: American Council on Consumer Interests, 102-10.

Phlips, Louis (1983), The Economics of Price Discrimination, New York, N.Y.: Cambridge University Press.

Plott, Charles R. (1981), "Experimental Methods in Political Economy: A Tool for Regulatory Research," in Attacking Regulatory Problems: An Agenda for Research in the 1980's, ed. A. R. Ferguson, Cambridge, Massachusetts: Ballinger Publishing Company, 117-43.

(1976), "Axiomatic Social Choice Theory: An Overview and Interpretation," American Journal of Political Science, 20 (3), 511-96.

Post, James E. (1986), "First World Foods/Third World Markets: Consumer Issues of the 1980's," Working Paper, School of Management, Boston University.

(1985), "Assessing the Nestle Boycott: Corporate Accountability and Human Rights," California Management Review, 27 (Winter), 113-31.

and Edward Baer (1978), "Demarketing Infant Formula: Consumer Products in the Developing World," Journal of Contemporary Business, 7 (4), 17-35.

Png, I.P.L. and D. Hirschleifer (1986), "Price Discrimination Through Offers to Match Price," University of California, Los Angeles Working Paper Series, Center for Marketing Studies, Paper No. 151.

Preston, Lee E. and Paul N. Bloom (1986), "The Concerns of the Rich/Poor Consumer," in The Future of Consumerism, eds. P.N. Bloom and R. Belk Smith, Lexington, MA: Lexington Books, 37-58.

Price, Linda L., Lawrence F. Feick and Robin A. Higie (1987), "Information Sensitive Consumers and Market Information," Joumal of Consumer Affairs, 21 (Winter), 328-41.

$\longrightarrow$, - and _- "Preference Heterogeneity and Coorientation as Determinants of Perceived Informational Influence," Journal of Business Research, (Forthcoming).

Pridgen, Dee and Ivan L. Preston (1980), "Enhancing the Flow of Information in the Marketplace: From Caveat Emptor to Virginia Pharmacy and Beyond at the Federal Trade Commission," Georgia Law Review, 14 (Summer), 635-80.

Rawls, John (1971), A Theory of Justice, Cambridge, MA: Harvard University Press.

Reich, Michael (1988), "International Trade and Trade-Offs For Third World Consumers," in The Frontier of Research In The Consumer Interest, ed. E. Scott Maynes and ACCI Research Committee, Columbia, MO: American Council on Consumer Interests, 375-96.

Rescher, Nicolas (1983) Risk: A Philosophical Introduction to the Theory of Risk Evaluation and Management, Washington, D.C.: University Press of America.

(1980) Unpopular Essays on Technological Progress, Pittsburgh, PA: University of Pittsburgh Press.

Rokeach, Milton (1974), The Nature of Human Values, New York: The Free Press.

Rosenthal, Robert W. (1980), "A Model in Which an Increase in the Number of Sellers Leads to a Higher Price," Econometrica, 48 (September).

Russo, J. Edward (1988), "Information Processing From the Consumer's Perspectives," in The Frontier of Research In The Consumer Interest, ed. E. Scott Maynes and ACCI Research Committee, Columbia, MO: American Council on Consumer Interests, 185-218.

_, Richard Staelin, Catherine A. Nolan, Gary J. Russell, Barbara L. Metcalf (1986), "Nutrition Information in the Supermarket," Journal of Consumer Research, 13 (June), 48- 70.

Sah, R. K. and J. E. Stiglitz (1986), "The Architecture of Economic Systems," The American Economic Review, 76 (September), 716-27.

Salop, S. (1986), "Practices that (Credibly) Facilitate Oligopoly Coordination," New Developments in the Analysis of Market Structure, eds. Joseph E. Stiglitz and G. Frank Mathewson, Cambridge, MA: MIT Press, 265-90.

(1977), "The Noisy Monopolist: Imperfect Information, Price Dispersion, and Price Discrimination," Review of Economic Studies, 44, 393-406. 

240-45.

(1976), "Information and Monopolistic Competition," American Economic Review, 66 (May),

Sawhill, Isabel V. (1988), "Poverty in the U.S.: Why Is It So Persistent?," Joumal of Economic Literature, 26 (September), 1073-119.

Schuker, Raymond E., Raymond C. Stokes, Michael L. Stewart, and Douglas P. Henderson (1984), "The Impact of the Saccharin Warning Label of Sales of Diet Soft Drinks in Supermarkets," Journal of Public Policy and Marketing, 2, 46-56.

Schwartz, Alan and Louis L. Wilde (1982), "Competitive Equilibria in Markets for Heterogeneous Goods Under Imperfect Information: A Theoretical Analysis with Policy Implications," The Bell Journal of Economics, 13 (1), 181-93.

Schwartz, Teresa M. (1977), "Regulating Unfair Practices Under the FTC ACT: The Need for a Legal Standard of Unfairness," Akron Law Review, 11 (Summer), 1-28.

Sen, Amartya K. (1985), "Social Choice and Justice: A Review Article," Jourmal of Economic Literature, 23 (December), 1764-76.

Shilony, Yuval (1977), "Mixed Pricing in Oligopoly," Journal of Economic Theory, 14 (April), 373-88.

Silverman, Milton, Philip R. Lee, and Mia Lydecker (1988), Prescriptions for Death: The Drugging of the Third World, Berkeley, CA: University of California Press.

(1976), The Drugging of the Americas, Berkeley, CA: University of California Press.

Singer, Hans (1975), “The Distribution of the Gains from Trade and Investment-Revisited," Journal of Development Studies, 11 (4), 376-82.

Sowell, Thomas (1981), Markets and Minorities, New York: Basic Books.

Staelin, Richard (1980), "Appliance Performance Labeling and Point-of-Purchase Information: The Results of Three Experiments," in Product Labeling and Health Risks, eds., L. Morris, M. Mazis, and I. Barofsky, Cold Spring Harbor Laboratory, 55-73.

Stern, Louis and Thomas Eovaldi (1984), Legal Aspects of Marketing Strategy, Englewood Cliffs, N.J.: Prentice-Hall, Inc.

Stokey, Edith and Richard Zeckhauser (1978), A Primer for Policy Analysis. New York: Norton.

Sturdivant, F. (1968), "Better Deal for Ghetto Shoppers," Harvard Business Review, 46 (March-April), 130-39.

Telser, L. G. (1973), "Searching for the Lowest Price," American Economic Review, 63 (May), 41- 49. (1965), "Abusive Trade Practices: An Economic Analysis," Law and Contemporary Problems, $30,488-505$.

Thompson, Fred and L.R. Jones (1982). Regulatory Policy and Practices. New York: Praeger.

Thorelli, Hans B. and Jack L. Engledow (1980), "Information Seekers and Information Systems: A Policy Perspective," Journal of Marketing, 44 (Spring), 9-27.

- and Sarah V. Thorelli (1977), Consumer Information Systems and Consumer Policy. Cambridge, MA: Ballinger Publishing Company.

Trobetta, William L. and Fred W. Morgan (1982), "Market Segmentation and Product Liability," Journal of Public Policy and Marketing, 1, 15-24.

Varian, Hal R. (1980), "A Model of Sales," American Economic Review, 70 (September), 651-59.

Velasquez, Manual (1982), Business Ethics: Concepts and Cases, Englewood Cliffs, N.J.: Prentice Hall.

Wall, Marjorie, Lois E. Dickey and W. Wayne Talarzyk (1977), "Predicting and Profiling Consumer Satisfaction and Propensity to Complain," in Consumer Satisfaction, Dissatisfaction and Complaining Behavior, ed. Ralph L. Day, Bloomington, IN: Indiana University Press, 91-101.

Wilkie, William L. (1987), "Affirmative Disclosures at the FTC: Communication Decisions," Journal of Marketing and Public Policy, 6, 33-42.

(1986), "Affirmative Disclosures at the FTC: Strategic Decisions," Journal of Marketing and Public Policy, 5, 123-45.

(1985), "Affirmative Disclosures at the FTC: Objectives for the Remedy and Outcomes of Past Orders," Journal of Public Policy and Marketing, 4, 91-111.

(1983), "Affirmative Disclosures at the FTC: Theoretical Framework and Typology of Case Selection," Journal of Marketing and Public Policy, 2, 3-15.

(1982), "Affirmative Disclosure: Perspectives on FTC Orders," Journal of Marketing and

Public Policy, 1, 95-110. 
Wilson, James Q. (1980), The Politics of Regulation, New York, N.Y.: Basic Books.

Wimmer, Frank (1981) “Lower Buying Efficiency Among Low Income Consumers-An Empirical Test and a Theoretical Extension of the Thesis 'The Poor Pay More' with Respect to the Federal Republic of Germany," Journal of Consumer Policy, 5 (1 and 2), 64-87.

Yankelovich, Daniel (1981), New Rules, New York, NY: Random House.

Zaltman, Gerald and Robert Duncan (1977), Strategies for Planned Change, New York, NY: John Wiley \& Sons. 